Journal of Social Sciences 8 (2): 163-169, 2012

ISSN 1549-3652

(C) 2012 Science Publications

\title{
Teachers View on Social and Emotional Aspect of Pedagogical Competence
}

\author{
Inga Belousa and Skaidrite Uzulina \\ Institute of Sustainable Education, Faculty of Education and Management, \\ Daugavpils University, Latvia
}

\begin{abstract}
Problem statement: Bologna process challenges European higher education area by comparability and compatibility of several issues including educators' professional competence. However, through their educational philosophy and activity educators have discovered and shaped their own sense and meaning of pedagogical competence. During the time when teacher professional standard has been reexamined nationally, teachers' voice in Latvia is still poorly considered. Therefore, this article aims to provide a balance between two directions-'from-above' that implies policy and legislation and 'from-below' that stands for practitioners' own voice. Approach: This study is an attempt to enter into professional world of elementary school teachers and to describe how they interpret meaning of their pedagogical competence embodied in educational activity. Thus, this basic interpretive study reflects characteristics of phenomenology and constructionism. The data are collected through semi-structured interviews. The sample $(n=14)$ is created by snowball approach and includes teachers who represent different length of service, main ethnic backgrounds and geographical parts of Latvia. The data analysis implies identification of recurrent themes that emerge through the data. Results: As a result, the study provides a description of developed themes that illustrate elementary school teachers' understanding of social and emotional aspect of pedagogical competence. Conclusion: The developed themes are discussed in the context of Bologna initiatives in higher education, holistic understanding of pedagogical competence and sustainable development of teacher education.
\end{abstract}

Key words: Pedagogical competence, social and emotional aspect of competence, affective domain, holism, sustainability

\section{INTRODUCTION}

Bologna documents state that society's progress towards sustainable development is a prerequisite for the transition of education to learning outcomes (Kennedy et al., 2009b). Hence, they illustrate the necessity of changing the action teachers take as the agents of the educational process. The change of teachers' professional action conditions the necessity to revise the content of teachers' professional competence (Belousa and Uzulina, 2010). Bologna documents emphasize that in many countries in Europe as well as in Latvia there have been insufficient discussion of the issue of teachers' professional competence; they also summon for further investigations in this sphere (Kennedy et al., 2009a; Goodson and Lindblad, 2011).

The explanation of the content of teachers' professional competence reveals a certain diversity both at the level of Europe and Latvia, offering both a narrower and a wider view on teachers' professional competence which is accounted for by the know-how and skills needed (Maslo, 2006), the social and personal dimensions (Day, 2004; Carbonneau et al., 2008), professional identity (Pipere, 2007), the spiritual dimension (Belousa, 2005; 2008), unity of teachers' professional skills and personal traits and feelings (Day, 2004; Kennedy et al., 2009a), the importance of the emotional intelligence competence for a teacher is emphasized by (Palomera et al., 2008; Hawkey, 2006). The narrowest know-how and skill based account of the content of teachers' professional competence does not comply with the idea of learning outcome oriented education teachers' action, thus it is necessary to regard the wider, holistic account of teachers' professional competence that has been noted by (Zeichner et al., 1996; Sherman, 2004; Pipere, 2007; Belousa, 2008).

It is admitted in the national strategic documents of education in Latvia that it is insufficient to regard teachers' professional action just as transferring theoretical knowledge, indicating the necessity of

Corresponding Author: Inga Belousa, Institute of Sustainable Education, Faculty of Education and Management, Daugavpils University, Latvia 


\section{J. Social Sci., 8 (2): 163-169, 2012}

revising teachers' professional actions and along with it the theory based content of teachers' professional competence Latvia's Sustainable Development Strategy 2030, 2007. Many authors admit that investigation of the professional life experience of teachers is the most significant approach in theory and practice based balanced account of teachers' professional competence (Goodson and Lindblad, 2011; Goodson and Lindblad, 2011; Goodson and Lindblad, 2011). However, in the research discourse balance between the theoretical, legislative aspect and teachers' voice is not guaranteed. At present in Latvia formation of teachers' professional standard has been initiated at the national level where teachers are hardly listened to. Hence, the present article is aimed at including the lacking voice of teachers in the discussion on teachers' professional competence.

\section{MATERIALS AND METHODS}

Study design: The study described in this article reflects the methodology of a basic interpretive research that is one of qualitative research traditions. It holds an interest in how teacher educators construct and carry out their professional activities and interpret their experience related to the social and emotional aspects of their pedagogical competence. Thus, this basic interpretive study reflects characteristics of constructionism and phenomenology (Creswell, 1998; Tesch, 1990) that ensure both to teachers' interpretation of the essence, structure and meaning of their professional experience. The data were collected through semistructured professional life story interviews (Bauer et al., 2008; Adler and McAdams, 2007; Creswell, 1998) that were piloted at the beginning of the study.

Participants: Fourteen participants provided data for this study by sharing their professional life stories. The sample included teachers who represented different length of educational experience, diverse fields of subjects taught at school, main ethnic backgrounds characteristic of the cultural environment in Latvia, both sexes and all five geographical parts of Latvia.

The sample was created by the snowball strategy (Noy, 2008; Goodman, 1961; Heckathorn, 1997; 2002; Patton, 2002) that is also known as chain referral purposeful sampling. According to this strategy, each interviewed participant suggested to contact another teacher whom s/he knew to have an efficient cooperation with his/her students and whose students had significant learning outcomes, thus proving equal representation of the process and the outcome in the teacher's educational activity.
Snowball sampling was used to find educators with significant embodiment of social and emotional aspect of their pedagogical competence in their educational activity and to invite them to participate in the study. The use of snowballing to recognize and access this group of educators was the most adequate sampling strategy for this study.

Data collection: The data were collected through fourteen semi-structured professional life story interviews that lasted from 2-4h each. Interviews were conducted with elementary school teachers in their native-Latvian or Russian language. Interviews were conducted from July 2010-Feb. 2011. All the interviews were audio recorded and transcribed verbatim.

The aim of interviewing was to acquire the data on the way elementary school teachers interpret their experience related to social and emotional aspect of their pedagogical competence. The professional life story interview of teachers entails mutually structured open type questions divided into six parts. The sequence of questions reminds of a book of teacher professional life story, i.e., (1) teachers' basic beliefs and values; (2) compiling the book of professional life story- title, division in chapters, content of chapters; (3) major episodes in the professional life storysuccessful, happy moment, failure, a moment of regret; turning points; impact of childhood notions; moments of wisdom; (4) vision of the future; (5) challenges of professional action; (6) philosophy of life. The interview is completed by participants' general reflections on the interview.

Data analyses: Considering that teachers' professional competence is a social phenomenon influenced by the historical and cultural aspect and concerned with practices and methods that produce and share interaction, the ethnomethodological approach was used in data analysis (Garfinkel, 1994; 2002; Rawls, 2008). This approach is concerned with identifying teachers' underlying assumptions, values and implications for shaping their thoughts and professional activity. Data analysis started with recognition of particular essential reflections of teachers' experiences, afterwards the essential reflections were reduced to codes and themes that characterize the phenomenon under study were created.

Outcomes: The results of the study can be presented highlighting two major themes: (1) Dynamics of pedagogical competence development and (2) Diamond edges of pedagogical competence and four sub-themes: 


\section{J. Social Sci., 8 (2): 163-169, 2012}

(1) Direction from black-and-white to colorful expression, (2) Significance of surrounding environment and mentoring, (3) Retrospection of childhood experience, (4) Transformative experience and shifts.

Dynamics of pedagogical competence development: The first topic apparent in interviews is related to the dynamics of the understanding of teacher's mission. Teachers call the life stories of their profession adventure stories, novels full of emotional experience, doubts, insecurity, humour, feeling, obstacles. Titles of teachers' professional life stories point to a dynamic understanding of teacher's mission. Hence, Sandra calls her professional life story "Road to the unknown" and ris calls his "Per aspera ad astra", Inta calls hers "Road to..." dynamic marks also other titles of life story books.

Direction from black-and-white to colorful expression: Interviews reveal that in the first years of their teaching experience teachers' understanding of their mission has been black-and-white, dominated by maximalism and ambition that impeded the cooperation with learners.

Anna tells, "I had a lot of trouble with mastering the teacher's profession that was first of all due to my youth maximalism. It was hard for me to find a common language with children. I just saw only the right and the wrong. I wanted everyone to do the way I had imagined." Teachers point out those mutual relations of teacher and learners at the beginning of teacher's professional career were formed according to teacher's beliefs and preferences disregarding learners' feelings and needs. This situation provoked aggression and intolerance in mutual relations.

Everything cannot be ideal and unchanging at school; things do not always happen as the teacher has planned them to happen. Teacher should listen to learners and take immediate decisions according to the situation taking into consideration learners' opinion and their age group and individual peculiarities. Iveta tells, "Teacher does not have a ready-made recipe. If you managed it that way last time it does not mean you can repeat it again next time. One thing worked with one child but not with another. Each time you have to invent a new method." Accepting the diversity and flexibility of the learning process, listening to children, respecting their opinion, one may avoid conflicts and diminish the emotional strain; this is told by Anna, "I think there would be fewer conflicts between teachers and their learners if we listened to children and saidyou are right and just unobtrusively made some corrections in their ideas." Anna warns that school is no place for realizing one's ambitions, "I had made a mistake with my first pupils. Maybe those were my ambitions? Girls told me-you always want to impose your way." Yet from the present day perspective the teacher claims that now she "understands ambitious people better", understands their action and motives.

Diversity in the understanding of teachers' mission is manifested in communication with learners. Understanding their mission of being a friend, partner, colleague, supporter, teachers develop their relations with learners on the basis of equality thus facilitating children's motivation for learning. Iveta tells, "I consider teachers as friends."

The experience based understanding of teacher's mission opens up the whole range of colours in the learning process that relates it to positive mutual cooperation principles. In the course of time the understanding of teacher's mission makes the way from maximalism and ambitions to tolerance and empathy, "ability to accept someone the way s/he is".

Significance of surrounding environment and mentoring: Talking about the beginning of their teaching career, teachers mention fear, insecurity, indeterminacy, lack of self-assurance. Teachers found it difficult to integrate their theoretical knowledge and skills in educational study. Anna tells, "It was a tragedy when I just started working, when I came to school as a young girl. I did not know what to begin with and what to do. I was in such agony! I learned from my mistakes".

Teachers confirm that the dynamics of their professional competence was propelled by their wish and self-motivation to become good teachers. They learned from their own mistakes. Interviews show that, first, pedagogical competence was promoted by teachers' motivation, reflection and self-reflection.

Second, pedagogical competence and the dynamic of the understanding of teacher's mission were promoted by a colleague-mentor, someone on friendly terms and sympathizing with him/her. In the cases of success they are united by common interests. It is essential that mentor may be trusted. Kristine tells, "For me it's very essential what I have discussed with Ilze. Before I came to study at school I was less focused on people. Now I realize that instead of teaching to play the violin I study with a child by means of the violin." However, such cases are mentioned rather rarely and in most cases teachers improved their professional competence independently and without anyone's support.

Third, there are cases when teachers receive support on the part of school administration. Anna tells, "I had a good director of studies; somebody else would have scolded me but she talked to me, very much, invited to her study and talked to me on equal terms. 
She told me that it would never be the way I had imagined, the ideal way." The attitude of administration is vital for the teacher to feel support instead of being censured, to feel secure and appreciated. Otherwise teacher is bound to change profession. Andrejs tells, "The problem is the headmaster's personality, he is very authoritarian. I even stayed in my study all day so that I would not meet him because each time I would receive a negative shock, reprimand and all that makes up atmosphere at school." Authoritarian school administration style not only impedes the growth of teacher's professional competence but also forms a negative emotional background at school on the whole.

Fourth, the dynamics of teachers' professional competence and understanding of teacher's mission are related to exchange of experience among teachers, discussions of other teachers' experience-successes and failures. Teachers make this kind of reflection in informal talks with other colleagues as well as in stories of the experience of further educators of teachers.

Retrospection of childhood experience: A transforming impact has been left on teachers by contacts with their own teachers in their school years. Some of them based cooperation in the learning process on mutual respect and working on equal terms with their learners providing support, kindness and honesty. In their assessment of their educational study teachers concluded that they were trying to imitate the teaching style of those teachers that was often even unconscious. Andris tells:

There was a teacher whom I deeply respected as an educator and maybe I learned more from her and I probably tried to imitate her style in my own study, now that I think of it. She treated us as equals though we were in form 6, 7, as if we were her colleagues. Teachers project a model of an ideal teacher for their own study.

Teachers who had learned in the Soviet period recall with great emotion negative moments at school and their authoritarian teachers. They recall teachers who treated them with intolerance and unfairly. Anna tells, "I generally felt that we were sort of categorized, as my parents were factory workers while others had better positions and I was well aware of that attitude." In their own study teachers try to avoid similar mistakes because they know very well how learners feel in situations like that. Any situation at school must be solved from the learner's point of view; rash decisions are to be avoided, care and empathy based relations are the ideal model of the learning process in which child takes the central role. The negative and positive childhood experience is a retrospective basis for understanding teacher's mission and creating relationship with learners.
Teachers claim that their understanding of teacher's mission at the beginning of their teaching career was based on their personal experience gained in contact with their teachers in their own school years.

Transformative experience and shifts: Interviews make it obvious that teachers can single out events in their personal life that have affected their understanding of teacher's mission. These events have led to a revision of their educational study. First, it is related to changes in teachers' personal life and assuming new social roles, e.g., marriage, child-birth.

Second, admitting the close unity of 'teacher as a human' and 'teacher as a professional', teachers tell that the moments of crisis in their own personal life have made them reconsider their professional action and attitudes. Maija tells:

I started feeling children better. It happened 12-13 years ago. I looked at children from another angle. My own child had been operated on. And while I was standing behind the doors of the operating theatre I watched other parents. They all had tears in their eyes. Each of us was fighting for our child's life, for their health. And then it occurred to me-what is really important? At school I had been shouting-you don't learn! You haven't done it! But at the hospital they were all equal.

Along with the changing attitude towards school learners, teachers' professional competence emerges in a new quality.

Third, strong emotional experience in one's professional action, e.g., conflict situations with learners and parents, make one reevaluate constructively one's role in managing attitudes and the learning process.

The dynamics of teachers' professional competence is a process based on reflection and selfreflection. The aspect of feelings and emotions plays a basic role in one's transformative experience. This is brought out by Anna, "You learn during the whole of your life, life emerges not by academic proficiency but through understanding of oneself and others, life. I think that when I had got to know my negative traits, not got to know but realized that I had them, that they interfere with my communication with people, I started changing them bit by bit."

Diamond edges of pedagogical competence: The summary of the interview data brings out a statement that teachers' professional competence entails integration of theoretical knowledge and skills through teacher's personality. Teacher's personality is like a diamond with multicoloured edges forming a whole. The brilliance of the diamond depends on the way it is polished and treated, while teacher's radiance begins 


\section{J. Social Sci., 8 (2): 163-169, 2012}

with self-understanding, self-acceptance and a wish for further improvement. Teacher's ability to understand learner depends on the way teacher is able to understand him/herself and his/her action, feelings. Anita tells, "One must understand oneself and then one is able to listen to others".

Ability to form empathy based relations with school learners is the central edge of teachers' professional competence that reduces emotional strain and makes the learning process successful. Anita tells, "What is most important in teacher's profession is the ability to step into other person's shoes, see things from other's perspective. Then it may be understood very well why s/he does so, behaves so and perceives what is going on with reserve." According to teachers, communication and cooperation with learners is a particularly sensitive process and for its successful accomplishment teachers are to respect several preconditions-respect learners, not to humiliate or offend them; this is testified to by Maija's words, "Even if a child is a fifth former, s/he is a personality and is grown up, maybe not physically but mentally s/he is a personality and deserves respect". Teacher must think over both the words s/he is about to say and action, as well as each particular situation. Teacher must feel how learners feel in the given moment in order not to offend them, not to cause conflict situation and diminish their wish to act. According to the acquired data, the basic principles of a successful communication of teacher and learner are as follows: cooperation must be based on honesty and principles of equality-equal demands for both teacher and learner. The major precondition for this is teacher's ability to understand him/her, objectively consider and admit one's mistakes. Anna tells, "Honesty is a skill of acknowledging one's mistake, apologize to children, for instance, enter the classroom and say-children, forgive me, please." Understanding themselves and others teachers form tolerance based learning process and cooperation. Maija tells, "Each of us is the way we are. This is what really forms life. None of us is either black or white. Of course, there are outcasts, castaways, but one must try to accept them." Teachers claim that major principles of a successful learning process are humour, emotions, feelings and social flexibility. Maija tells:

I realized one thing-so much depends on teacher. Teacher is much guided by feelings in his/her work. For instance, when I get ready for a class I cannot say whether everything will go precisely according to the plan. I cannot predict at once that in this class I will study with just this or that method. I run a class and I feel that this class needs it somewhat differently. I don't know what it is. It comes from inside through feelings.
Teachers claim that humour in communication enhances the formation of a positive emotional environment and the process of cognition, humour makes it easier for learners to understand complicated topics and memorize them better. Maija tells, "I enter the class with humour so that children would feel and perceive the material better. I am emotional myself. When I'm telling things I display emotions-by gestures, facial expressions. Especially if you see that then they wish to act and understand, then they really do."

It may be concluded that teachers' professional competence is based on self-understanding and selfawareness, empathy, tolerance, flexibility in managing relations and the learning process whereby specific professional knowledge and skills get integrated.

\section{RESULTS AND DISCUSSION}

The research data prove that the socio-emotional aspect of teachers' professional competence is not static but dynamic. The dynamics of teachers' professional competence at various levels may be related to different international discussions (Spencer and Spencer, 1993; Bowden and Marton, 2004). The lowest level of teachers' professional competence called by some authors the level of qualification is based on knowledge and professional know-how. Yet the analysis of the research data leads to the conclusion that knowledge and professional know-how based characteristics of teachers' professional competence is insufficient. One of the major edges of professional competence is its socio-emotional aspect that is no invariant component but a transformative process instead.

Bowden and Marton (2004), in turn, suggest the conception of four different professional competence models. They are hierarchically structured in relation to one another. Analyzing theoretical models of professional competence and teacher identity (e.g., Beijaard et al., 2004; Korthagen, 2004) and the research data, a conclusion has been made that topics deduced from the research data analysis gain resonance in the latest discourse on teachers' professional competence and its essence all over the world.

\section{CONCLUSION}

The aim of the research was to trigger off a discussion of teachers' professional competence with special emphasis on the teachers' opinion that sets a balance between the theoretical and experience based account of teachers' professional competence. According to the data gained, teachers' professional competence is based on, first of all, teachers' ability of 
understanding themselves, their own emotions, motivation, or the emotional aspect. Second comes teachers' ability to feel empathy with learners and develop relations with them rooted in empathy and tolerance, or the social aspect. To understand learners, teachers must first understand themselves and this brings together both the emotional and social aspects.

The data acquired within the research testify to the fact that the dynamics of the socio-economic aspect is related to several factors. One of them is the transformative experience that teachers have gained in the course of their professional career. Their childhood experience of contacting teachers is also significant. Communication with teachers-mentors and friends and experience exchange with them is also important. Certain corrections are introduced by the change of the social role and critical moments of break in their personal and professional life.

Hence, it is necessary to use in the process of teacher education and further education cooperation facilitating forms of work related to teachers' reflection and self-reflection. Reflection and self-reflection based further education process enhances the development of teachers' social and emotional competence.

\section{ACKNOWLEDGMENT}

The preparation of this manuscript was supported by the ESF grant "Atbalsts Daugavpils Universitates doktora studiju istenosanai" (agreement No. 2009/0140/1DP/1.1.2.1.2/09/ipia/viaa/015)

\section{REFERENCES}

Adler, J.M. and D.P. McAdams, 2007. Time, culture and stories of the self. Psychol. Inquiry, 18: 97-99. DOI: $10.1080 / 10478400701416145$

Bauer, J.J., D.P. McAdams and J.L. Pals, 2008. Narrative identity and eudaimonic well-being. J. Happiness Stud., 9: 81-104. DOI: 10.1007/s10902006-9021-6

Beijaard, D., P. Meijer and N. Verloop, 2004. Reconsidering research on teachers' professional identity. Teach. Teacher Educ., 20: 107-128. DOI: 10.1016/j.tate.2003.07.001

Belousa, I. and S. Uzulina, 2010. Emotional aspect of teachers' professional mastery in Latvia: Theoretical and historical reflections. Discourse Commun. Sustain. Dev., 1: 82-94.

Belousa, I., 2005. Spirituality as a Dimension of Education: Reimaging and Reconstructing Teacher Education in Latvia. Ph.D Thesis, Fordham University, USA.
Belousa, I., 2008. Rediscovery of silenced inner wisdom of spirituality: Teachers' voice in the contemporary post-Soviet era. Int. J. Children's Spirituality, $\quad 13$ : 39-49. DOI: 10.1080/13644360701834825

Bowden, J. and F. Marton, 2004. The University of Learning: Beyond Quality and Competence. 1st Edn., Routledge, ISBN-10: 0415334918, pp: 320.

Carbonneau, N., R.J. Vallerand, C. Fernet, F. Guay, 2008. The role of passion for teaching in intrapersonal and interpersonal outcomes. J. Educ. Psychol., 100: 977-987. DOI: 10.1037/a0012545

Creswell, J.W., 1998. Qualitative Inquiry and Research Design: Choosing among Five Traditions. 1st Edn., Sage Publications, London, ISBN-10: 0761901434, pp: 403.

Day, C., 2004. A Passion for Teaching. 1st Edn., Routledge Falmer, London, ISBN: 041525180X, pp: 204.

Garfinkel, H., 1994. Studies in Ethnomethodology. 1st Edn., Wiley-Blackwell, Cambridge, ISBN: 0745600050, pp: 288.

Garfinkel, H., 2002. Ethnomethodology's Program: Working out Durkeim's Aphorism. 1st Edn., Rowman and Littlefield, New York, ISBN: 0742516423, pp: 299.

Goodman, L.A., 1961. Snowball Sampling. Ann. Math. Stat., 32: $148-170 . \quad$ DOI: 10.1214/aoms/1177705148

Goodson, I. and S. Lindblad, 2011. Professional Knowledge and Educational Restructuring in Europe. 1st Edn., Sense Publishers, Rotterdam, ISBN-10: 9460913784, pp: 109.

Hawkey, K., 2006. Emotional intelligence and mentoring in pre-service teacher education: A literature review. Mentor. Tutor., 14: 137-147. DOI: $10.1080 / 13611260500493485$

Heckathorn, D.D., 1997. Responded-driven sampling: A new approach to the study of hidder populations. Soc. Prob., 44: 174-199. DOI: 10.1525/sp.1997.44.2.03x0221m

Heckathorn, D.D., 2002. Respondent-Driven Sampling: Deriving valid estimates from Chain-referral samples of hidden populations. Soc. Prob., 49: 11-34. DOI: 10.1525/sp.2002.49.1.11

Kennedy, D., A. Hyland and N. Ryan, 2009a. B 2.3-3 Learning Outcomes and Competences. EUA Bologna Handbook.

Kennedy, D., A. Hyland and N. Ryan, 2009b. C 3.4-1 Writing and Using Learning Outcomes: A Practical Guide. EUA Bologna Handbook. 
Korthagen, F.A.J., 2004. In search of the essence of a good teacher: Towards a more holistic approach in teacher education. Teach. Teacher Educ., 20: 7797. DOI: $10.1016 /$ j.tate.2003.10.002

Maslo, I., 2006. Maciaanas daudzveidibas Izpratne Integrativo Procesu Teorija, (Understanding of Learning Diversity in the Theory of Integrative Processes). In: No Zinasanam UN Kompetentu Darbibu: Macisanas Antrpologiskie, Etiskie un Socialkritiskie Aspekti (From Knowledge to Competent Activity: Anthropological, Ethical and Social-Critical Aspects of Learning, Maslo, I. (Ed.). LU Akademiskais Apgads, Riga, pp: 20-44.

Noy, C., 2008. Sampling Knowledge: The hermeneutics of snowball sampling in qualitative research. Int. J. Soc. Res. Meth., 11: 327-344. DOI: 10.1080/13645570701401305

Palomera, R., P. Fernandez-Berrocal and M.A. Brackett, 2008. Emotional intelligence as a basic competency in pre-service teacher training: Some evidence. Elect. J. Res. Educ. Psychol., 6: 437-454.

Patton, Q.M., 2002. Qualitative Research and Evaluation Methods. 3rd Edn., Sage Publication, Newbury Park, California, ISBN-10: 0761919716, pp: 598.
Pipere, A., 2007. Education and Sustainable Development: First Steps toward Changes. Daugavpils University, Daugavpils.

Rawls, A.W., 2008. Harold Garfinkel, ethnomethodology and workplace studies. Organ. Stud., 29: 701-732. DOI: $10.1177 / 0170840608088768$

Sherman, S., 2004. Responsiveness in teaching: Responsibility in its most particular sense. Educ. Forum, 68: 115-125. DOI: 10.1080/00131720408984618

Spencer, L.M. and S.M. Spencer, 1993. Competence at work: Models for Superior Performance. 1st Edn., John Wiley Sons, New York, pp: 372.

Tesch, R., 1990. Qualitative Research: Analysis Types and Software Tools. 1st Edn., Routledge, New York, ISBN-10: 1850006091, pp: 330.

Zeichner, K.M., S.L. Melnick and M.L. Gomez, 1996. Currents of Reform in Preservice Teacher Education. 1st Edn., Teachers College Press, New York, ISBN-10: 0807734292, pp: 246. 